\title{
Seasonal Stock Return Patterns In The Seven Industrialized Nations
}

Jayen B. Patel (E-mail: jpatel@adelphi.edu), Adelphi University

Dorla A. Evans (E-mail: evansd@email.uah.edu), University of Alabama, Huntsville

\begin{abstract}
The paper extends research on the January effect on the $G 7$ countries by evaluating it by decade through 2001. The January effect peaked during the 1970s and is smaller and less common in recent years. The data reveal a marked seasonal return pattern with higher returns in December through May than in June through November. The pattern, not related to the January effect, is more common in recent years.
\end{abstract}

\subsection{Introduction}

he finance literature is replete with reports of return patterns in financial markets. Return patterns, or anomalies, are clearly inconsistent with the widely accepted notion of efficient markets. Although researchers have accepted the existence of persistent market anomalies, they have been largely unsuccessful in explaining them.

The January effect is one of the more publicized anomalies. It refers to the phenomenon of stock return premiums' (especially on small stocks) being earned in the first ten trading days of January. In this paper we document the January effect by decade from 1960 to 2001 for each of the seven most industrialized nations, the G7 countries. Included are the U.S., the U.K., Canada, Japan, France, Germany, and Italy.

We also identify a semi-year seasonal pattern in these countries -- the mean stock returns in December to May are greater than those in June to November. The pattern is not related to the January effect. And, unlike the January effect, the seasonal pattern is more prevalent in recent years.

The G7 countries are of interest due to their dominance in world equity markets. Because of greater informational efficiencies, the G7 countries should have a greater degree of market integration than other countries. Alford (1993) argues that market integration should result in the disappearance of any systematic patterns in recent years.

\subsection{Literature Review}

Haugen and Jorion (1996) presented evidence of a continued January effect, nearly two decades after its rediscovery by Rozeff and Kinney (1976). Using data for all the New York Stock Exchange firms from 1926 to 1993, they found (1) the January effect existed in every decile of firm size but the two largest and (2) its magnitude decreased by decile. Relative to other five-year periods between 1964 and 1993, the period of 1974 to 1978 exhibited unusually large January excess returns, particularly in the smaller firm-size deciles.

Several hypotheses have been offered to explain the January effect, although there is no consensus among researchers. The tax-loss-selling hypothesis states that investors sell stock with losses in December in order to use the capital losses to offset taxable capital gains in the year's tax return. The large volume of stock selling reduces prices in December. In January investors may earn abnormally high returns by buying stock at the reduced December prices.

Readers with comments or questions are encouraged to contact the authors via email.

Another hypothesis for the January effect is delayed, yet significant, information releases from year-end 
reporting (Jones and Lee, 1995). Others argue the effect is caused by investors' over-reacting to new information (DeBondt and Thaler, 1987) or by data or statistical biases (Roll, 1983; Blume and Stambaugh, 1983).

Bhabra, Dhillon, and Ramirez (1999) used a natural experiment to test the tax-loss-selling hypothesis for the January effect and a newly-hypothesized November effect. The Tax Reform Act of 1986 eliminated the reduced tax treatment of capital gains, increasing the incentive for investors to offset capital gains with capital losses before the end of the tax year in December. The authors found evidence to support a strengthening of the January effect after the implementation of the Act.

The Tax Reform Act of 1986 also changed the end of the fiscal year for all mutual funds from December to October. Bhabra, et al. (1999) hypothesized a post-Act initiation of a November effect from tax-loss-selling pressures. Like other investors, mutual fund managers have greater incentives to sell stock losers in the last month of the fiscal year to offset taxable capital gains, causing abnormal gains in the following month. Their analysis supported a November effect in stock returns.

In a much earlier study, Gultekin and Gultekin (1983) reviewed stock return data from 1959 to 1979 with an eye toward explaining the January effect with the tax-loss-selling hypothesis. Using data from 17 countries, including the G7, they reported that stock market returns in 12 of the countries exhibited seasonality. Most often the seasonality coincided with the month which was the beginning of the tax year in the particular country -- mostly January, except for April in the U.K.

Yet, Gultekin and Gultekin (1983) found no seasonal effect at all for France, Italy, or a value-weighted U.S. index. They found that January returns were significantly larger than returns in most other months. However, they could not conclude that January returns significantly differed from returns in all other months. The latter suggests a seasonal pattern broader than the January effect. It is this result we wish to study further.

Chen and Chan (1997) examined for seasonality eleven different U.S. financial data series (stock, bonds, bills, various premia) from 1926 through 1990, controlling for economic condition. Six of the series showed no seasonality. Small firm stocks exhibited a January effect in all economic conditions but a stronger effect during economic expansions. Chen and Chan found large stocks have strong summer returns, again suggesting a broader seasonal pattern of stock returns. The rest of the series presented very complex and differing patterns of seasonality in varying months in varying economic conditions. The authors included economic condition in their study because they focused on a broad spectrum of financial instruments, which behave very differently in different economic conditions.

Agrawal and Tandon (1994) examined five different seasonal patterns with data from 1971 to 1987 for 18 countries, including the G7. They could not reject the null hypothesis of equal monthly returns for Canada or Germany. Furthermore, their mean monthly return data suggest seasonal patterns broader than the January effect, although they did not address the pattern.

Alford and Guffey (1996) examined seasonality (not specifically the January effect) in 18 countries (including the G7) over two time periods - 1970 to 1994 and 1983 to 1994. They analyzed return data stated in U.S. dollars versus the local currency using two different statistical tests, ANOVA and Friedman Rank Sums. Their data for the G7 presented evidence of seasonality from 1970 to 1994 for Canada, France, Germany, and Italy, but not for Japan, the U.K., or the U.S. Only France had significant seasonality in the more recent data. Alford and Guffey reported that seasonalities may be found in one time period but not another, using local currency versus U.S. dollars, using one statistical test versus the other. They concluded that seasonalities may not exist and that investors may not be able to utilize the patterns to their benefit.

Durham (2001) and Chien, Lee, and Wang (2002) also addressed the possible statistical bias explanation for anomalies. Durham examined the sensitivity of stock return anomalies in sixteen developed countries to statistical specification bias. He concluded that the January effect was robust even with models which control for specification bias. Chien, Lee, and Wang evaluated the statistical deficiencies associated with using the dummy variable regression models in seasonality research. They found that when stock returns become highly volatile, seasonality patterns may 
be erroneously found.

Alford (1993) argued that the world's capital markets are becoming more integrated. More integration results from greater informational efficiency which should result in fewer exploitable return patterns in the world's stock markets. An implication of Alford's work is that fewer examples of seasonal effects should exist in better integrated markets and in the more recent stock return data. Alford's argument suggests that the study of seasonal effects across countries is valuable to understanding anomalies.

The literature has demonstrated the persistence of the January effect across countries and has suggested, but not pursued, broader seasonality patterns. Consensus has still not been reached in explaining the anomalies. Identifying patterns remains a far simpler task than explaining them.

In this study we extend the research on the January effect for the G7 countries across four decades through 2001. Furthermore, we look for a broader seasonal effect suggested by our data and data reported in some earlier studies.

\subsection{Data}

Monthly return data from January 1960 through December 2001 were collected for representative stock indexes for the G7 countries. Data for January 1960 through December 1995 (base year 1967) were retrieved from the Internet web site, Economic Time Series Page (http://www.economagic.com). Data from this site are frequently changed and updated. The index values are also published in the Survey of Current Business. We added data from the latter source for the period January 1996 through December 2001. The index values for January 1996 through December 1998 and January 1999 to December 2001 have base years, respectively, of 1990 and 1995.

We excluded Japan's returns for 2000 due to unavailability of index values for some months in that year. There are 504 observations for each stock market series, with the exception of Japan, which has 492.

\subsection{Results}

Table 1 contains the mean returns of each country's stock market by months. The U.S. stock market generated a mean monthly return of $0.64 \%$ over the period January 1960 to December 2001. During the same time period, the U.K. (0.74\%), France $(0.73 \%)$ and Italy $(0.74 \%)$ generated comparatively higher returns; whereas, Germany $(0.49 \%)$, Japan $(0.66 \%)$ and Canada $(0.63 \%)$ generated lower mean monthly returns.

TABLE 1: Mean Monthly Stock Returns of the G7 Nations January 1960 to December 2001

\begin{tabular}{lccccccc}
\hline Month & U.S. & U.K. & Canada & Japan $^{\text {a }}$ & France & Germany & Italy \\
\hline January & 1.68 & 2.80 & 2.13 & 2.64 & 3.35 & 2.21 & 3.27 \\
February & 1.10 & 2.31 & 0.35 & 1.65 & 1.07 & 1.71 & 3.16 \\
March & 0.72 & 1.38 & 0.69 & 1.01 & 1.48 & 1.15 & 1.58 \\
April & 1.03 & 1.56 & 0.64 & 1.58 & 2.33 & 1.22 & 1.20 \\
May & 0.53 & 1.49 & 0.42 & 1.43 & 0.32 & -0.22 & 0.82 \\
June & 0.27 & -0.93 & -0.41 & 0.19 & -1.83 & 0.23 & -1.42 \\
July & 0.22 & -0.50 & 0.82 & 0.54 & 0.79 & -0.14 & 0.11 \\
August & 0.19 & 0.57 & 0.51 & -0.69 & 1.28 & -1.15 & 2.04 \\
September & -0.16 & 0.14 & -1.15 & -0.61 & -0.84 & -1.59 & -0.82 \\
October & 0.09 & -0.45 & -0.63 & -1.38 & -1.25 & -0.78 & -0.92 \\
November & 1.03 & -0.07 & 1.77 & 0.83 & 0.82 & 0.22 & -0.22 \\
December & 0.95 & 0.51 & 2.39 & 0.67 & 1.28 & 0.71 & 0.03 \\
\hline Average & $\mathbf{0 . 6 4}$ & $\mathbf{0 . 7 4}$ & $\mathbf{0 . 6 3}$ & $\mathbf{0 . 6 6}$ & $\mathbf{0 . 7 3}$ & $\mathbf{0 . 4 9}$ & $\mathbf{0 . 7 4}$ \\
\hline R & & & & &
\end{tabular}

a Returns for Japan do not include data for 2000.

We subjected the data to standard analyses of variance (ANOVA) to determine whether mean monthly returns in one period differ significantly from returns in other periods. We first test a January effect on the full series 
of data from 1960 through 2001.

$H_{01}: \quad r_{i j a n}=r_{i \text { Feb-Dec }}$

$\mathbf{H}_{\mathrm{a} 1}: \quad \mathbf{r}_{\mathrm{i} \text { Jan }} \neq \mathbf{r}_{\mathrm{i} \text { Feb-Dec }}$

where $\mathbf{r}_{\mathbf{i} \text { Jan }}$ is the average return from January for country $\mathbf{i}, \mathbf{r}_{\mathbf{i} \text { Feb-Dec }}$ is the average return on the remaining eleven months for each country i.

In Table 2 each country has a significantly higher average return ( $p$-value .05) in January than across the remaining months of the year, confirming the existence of a January effect in the full data series. The January effect is seen in large capitalization stocks included on each countries' major indexes.

TABLE 2: ANOVA of Mean Returns of January versus February-December January 1960 to December 2001

\begin{tabular}{|c|c|c|c|c|}
\hline Country & January & Feb-Dec & F-value & $p$-value \\
\hline U.S. & $\begin{array}{l}1.68^{* *} \\
(3.24)\end{array}$ & $\begin{array}{c}0.54 \\
(3.41)\end{array}$ & 4.312 & .038 \\
\hline U.K. & $\begin{array}{l}2.80^{* * * *} \\
(4.14)\end{array}$ & $\begin{array}{r}0.55 \\
(4.72)\end{array}$ & 8.966 & .003 \\
\hline Canada & $\begin{array}{l}2.13^{* *} \\
(5.24)\end{array}$ & $\begin{array}{c}0.49 \\
(4.45)\end{array}$ & 5.066 & .025 \\
\hline Japan $^{\text {a }}$ & $\begin{array}{l}2.64 * * * \\
(4.02)\end{array}$ & $\begin{array}{c}0.48 \\
(4.63)\end{array}$ & 8.370 & .004 \\
\hline France & $\begin{array}{l}3.35 * * * \\
(9.26)\end{array}$ & $\begin{array}{c}0.50 \\
(5.50)\end{array}$ & 9.022 & .003 \\
\hline Germany & $\begin{array}{l}2.21 * * * \\
(4.29)\end{array}$ & $\begin{array}{c}0.33 \\
(4.50)\end{array}$ & 6.741 & .010 \\
\hline Italy & $\begin{array}{c}3.27 * * \\
(6.55) \\
\end{array}$ & $\begin{array}{c}0.51 \\
(6.77) \\
\end{array}$ & 6.467 & .011 \\
\hline
\end{tabular}

${ }^{a}$ Returns for Japan do not include data for 2000 .

Numbers in parentheses are standard deviations.

*** and ** indicate January returns are significantly different from February-December returns at .01 and .05 levels, respectively.

We conducted ANOVA to test the January effect for each country in each decade k: 1960s, 1970s, 1980s, and 1990s through 2001. According to Alford (1993), we should find fewer examples of significant seasonalities in the G7 markets in later decades. The hypotheses are:

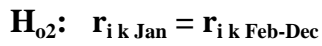

$\mathbf{H}_{\mathrm{a} 2}: \mathbf{r}_{\mathrm{ikJan}} \neq \mathbf{r}_{\mathrm{i} \text { k Feb-Dec }}$

We separate the monthly return data for each country across decades in Table 3 . In 26 of the 28 cases, the mean return in January appears greater than the mean returns in February through December. However, not all the differences in these cases are statistically significant. In the 1960s only Japan has a statistically significant January effect ( $p$-value < $.05)$. In the 1970 s all of the G7 countries exhibit a January effect ( $p$-value $<.10$ ), with the exception of Italy. Only the U.K. has a significant January effect in the 1980s. Only Germany and Italy have a significant January effect in the 1990 s.

Thus, the January effect seems mostly a phenomenon of the 1970s. Our results differ from Haugen and Jorion (1996) who show the persistence of the U.S. January effect into the 1990s. Their data, however, only go through 1993. We also differ somewhat from Gultekin and Gultekin (1983). They found no seasonal effect for France, Italy, or the U.S. in data from 1959 to 1979. 
TABLE 3: ANOVA by Decade of Mean Monthly Returns of January versus February-December

\begin{tabular}{|c|c|c|c|c|c|c|c|c|}
\hline Country & January & Feb-Dec & F-value & $p$-value & January & Feb-Dec & F-value & $p$-value \\
\hline \multicolumn{5}{|c|}{ Panel A: 1960-1969 } & \multicolumn{4}{|c|}{ Panel C: 1980-1989 } \\
\hline U.S. & $\begin{array}{l}1.05 \\
(3.33)\end{array}$ & $\begin{array}{c}0.35 \\
(2.95)\end{array}$ & 0.516 & .474 & $\begin{array}{l}2.03 \\
(3.25)\end{array}$ & $\begin{array}{r}0.96 \\
(3.78)\end{array}$ & 0.748 & .389 \\
\hline U.K. & 1.62 & 0.28 & 1.482 & .226 & $3.72 *$ & 1.27 & 2.964 & .088 \\
\hline & $(2.19)$ & $(3.42)$ & & & $(3.50)$ & $(4.38)$ & & \\
\hline Canada & $\begin{array}{l}2.25 \\
(4.06)\end{array}$ & $\begin{array}{c}0.41 \\
(3.38)\end{array}$ & 2.639 & .107 & $\begin{array}{l}2.06 \\
(6.74)\end{array}$ & $\begin{array}{r}0.69 \\
(5.18)\end{array}$ & 0.611 & .436 \\
\hline Japan & $\begin{array}{l}4.74 * * \\
(2.76)\end{array}$ & $\begin{array}{r}0.37 \\
(5.53)\end{array}$ & 6.068 & .015 & $\begin{array}{l}3.20 \\
(2.70)\end{array}$ & $\begin{array}{r}1.46 \\
(3.38)\end{array}$ & 2.503 & .116 \\
\hline France & $\begin{array}{l}0.80 \\
(6.12)\end{array}$ & $\begin{array}{c}0.06 \\
(4.40)\end{array}$ & 0.239 & .626 & $\begin{array}{l}2.88 \\
(6.06)\end{array}$ & $\begin{array}{r}1.44 \\
(6.84)\end{array}$ & 0.413 & .522 \\
\hline Germany & $\begin{array}{l}1.66 \\
(4.97)\end{array}$ & $\begin{array}{r}0.44 \\
(5.46)\end{array}$ & 0.459 & .499 & $\begin{array}{l}0.85 \\
(5.15)\end{array}$ & $\begin{array}{r}1.01 \\
(4.29)\end{array}$ & 0.013 & .909 \\
\hline Italy & $\begin{array}{l}0.78 \\
(6.02)\end{array}$ & $\begin{array}{c}0.06 \\
(4.99)\end{array}$ & 0.182 & .670 & $\begin{array}{l}6.22 \\
(7.36)\end{array}$ & $\begin{array}{c}1.88 \\
(8.16)\end{array}$ & 2.625 & .108 \\
\hline \multicolumn{5}{|c|}{ Panel B: 1970-1979 } & \multicolumn{4}{|c|}{ Panel D: 1990-2001 } \\
\hline U.S. & $\begin{array}{l}2.57 * * \\
(4.07)\end{array}$ & $\begin{array}{c}-0.04 \\
(3.68)\end{array}$ & 4.409 & .038 & $\begin{array}{l}1.16 \\
(2.55)\end{array}$ & $\begin{array}{c}0.81 \\
(3.15)\end{array}$ & 0.139 & .710 \\
\hline U.K. & $\begin{array}{l}4.49^{*} \\
(6.79)\end{array}$ & $\begin{array}{c}0.29 \\
(6.98)\end{array}$ & 3.327 & .071 & $\begin{array}{l}1.61 \\
(2.44)\end{array}$ & $\begin{array}{r}0.39 \\
(3.39)\end{array}$ & 1.500 & .223 \\
\hline Canada & $\begin{array}{l}3.32 * \\
(6.54)\end{array}$ & $\begin{array}{r}0.34 \\
(4.42)\end{array}$ & 3.816 & .053 & $\begin{array}{l}1.10 \\
(3.78)\end{array}$ & $\begin{array}{r}0.52 \\
(4.66)\end{array}$ & 0.177 & .674 \\
\hline Japan $^{\text {a }}$ & $\begin{array}{l}4.57 * * * \\
(3.23)\end{array}$ & $\begin{array}{l}0.56 \\
(3.78)\end{array}$ & 10.503 & .002 & $\begin{array}{l}-1.53 \\
(3.81)\end{array}$ & $\begin{array}{r}-0.40 \\
(5.25)\end{array}$ & 0.491 & .485 \\
\hline France & $\begin{array}{l}7.57 * * * \\
(16.15)\end{array}$ & $\begin{array}{c}-0.13 \\
(5.85)\end{array}$ & 10.542 & .002 & $\begin{array}{l}2.36 \\
(4.74)\end{array}$ & $\begin{array}{r}0.59 \\
(4.67)\end{array}$ & 1.576 & .211 \\
\hline Germany & $\begin{array}{l}2.76^{* * * *} \\
(3.01)\end{array}$ & $\begin{array}{l}-0.42 \\
(3.32)\end{array}$ & 8.554 & .004 & $\begin{array}{l}3.35^{* *} \\
(3.97)\end{array}$ & $\begin{array}{r}0.31 \\
(4.61)\end{array}$ & 4.900 & .028 \\
\hline Italy & $\begin{array}{l}-0.03 \\
(5.52)\end{array}$ & $\begin{array}{c}-0.11 \\
(7.64)\end{array}$ & 0.001 & .978 & $\begin{array}{l}5.66 * * * \\
(5.60)\end{array}$ & $\begin{array}{r}0.24 \\
(5.87)\end{array}$ & 9.435 & .003 \\
\hline
\end{tabular}

${ }^{a}$ Returns for Japan do not include data for 2000.

Numbers in parentheses are standard deviations.

*** and ** indicate January returns are significantly different from February-December returns at .01 and .05 levels, respectively. 
At least for large capitalization stocks the January effect is not a consistent phenomenon. Long time series may contain subperiods like the 1970s with such dramatic January effects that they erroneously suggest the January effect exists for the entire period. Our data reveal considerable variation in the size of the January effect across years.

A review of mean returns in Table 1 reveals the relative uniformity across the G7 countries of six-month periods with higher returns. Returns in December through May most often appear greater than in June through November. Intrigued, we reviewed statistics in prior studies, particularly Gultekin and Gultekin (1983) and Agrawal and Tandon (1994). Their data also suggest seasonal patterns that are broader than the January effect they studied. We tested the following hypotheses:

$\mathbf{H}_{\mathbf{0} 3}: \quad \mathbf{r}_{\mathrm{i} \text { Dec-May }}=\mathbf{r}_{\mathrm{i} \text { Jun-Nov }}$

$\mathbf{H}_{\mathrm{a} 3}: \quad \mathbf{r}_{\mathrm{i} \text { Dec-May }} \neq \mathbf{r}_{\mathbf{i} \text { Jun-Nov }}$

Panel A of Table 4 reveals a strong six-month pattern ( $p$-value < .05) of returns over the 1960 to 2001 period, allowing us to reject the null hypothesis for each G7 country. In fact, in the period January 1960 to December 2001,5 of the 7 countries have negative mean returns during the months of June through November. We believe that we may have captured a semi-year effect that is broader than the well-documented January effect.

TABLE 4: ANOVA of Mean Monthly Returns December-May versus June-November January 1960 to December 2001

\begin{tabular}{|c|c|c|c|c|c|c|c|}
\hline \multicolumn{8}{|c|}{ Panel A: With January Returns } \\
\hline Country & Dec-May & & Jun-Nov & & F-value & & $P$-value \\
\hline U.S. & $\begin{array}{l}1.00 * * \\
(3.25)\end{array}$ & & $\begin{array}{c}0.27 \\
(3.52)\end{array}$ & & 5.827 & & .016 \\
\hline U.K. & $\begin{array}{l}1.68 * * * \\
(4.86)\end{array}$ & -0.21 & (4.36) & 20.882 & & .000 & \\
\hline Canada & $\begin{array}{l}1.10 * * \\
(4.23)\end{array}$ & & $\begin{array}{c}0.15 \\
(4.79)\end{array}$ & & 5.574 & & .019 \\
\hline Japan $^{\text {a }}$ & $\begin{array}{l}1.50^{* * * *} \\
(4.31)\end{array}$ & -0.19 & (4.77) & 16.927 & & .000 & \\
\hline France & $\begin{array}{l}1.64 * * * \\
(6.57)\end{array}$ & -0.17 & (5.10) & 11.944 & & .001 & \\
\hline Germany & $\begin{array}{l}1.13 * * * \\
(4.02)\end{array}$ & -0.15 & (4.88) & 10.372 & & .001 & \\
\hline Italy & $\begin{array}{l}1.68 * * * \\
(6.00)\end{array}$ & -0.20 & (7.38) & 9.859 & & .002 & \\
\hline \multicolumn{8}{|c|}{ Panel B: Without January Returns } \\
\hline U.S. & $\begin{array}{c}0.87 * \\
(3.24)\end{array}$ & & $\begin{array}{c}0.27 \\
(3.52)\end{array}$ & & 3.494 & & .062 \\
\hline U.K. & $\begin{array}{l}1.45^{* * * *} \\
(4.97)\end{array}$ & -0.21 & (4.36) & 14.512 & & .000 & \\
\hline Canada & $\begin{array}{c}0.90^{*} \\
(3.98)\end{array}$ & & $\begin{array}{c}0.15 \\
(4.79)\end{array}$ & & 3.222 & & .073 \\
\hline Japan $^{\text {a }}$ & $\begin{array}{l}1.27 * * * \\
(4.34)\end{array}$ & -0.19 & (4.77) & 11.344 & & .001 & \\
\hline France & $\begin{array}{l}1.30 * * * \\
(5.86)\end{array}$ & -0.17 & (5.10) & 8.293 & & .004 & \\
\hline Germany & $\begin{array}{l}0.92 * * \\
(3.94)\end{array}$ & & $\begin{array}{l}-0.15 \\
(4.88)\end{array}$ & & 6.504 & & .011 \\
\hline Italy & $\begin{array}{l}1.36^{* * *} \\
(5.85)\end{array}$ & & $\begin{array}{l}-0.20 \\
(7.38)\end{array}$ & & 6.177 & & .013 \\
\hline
\end{tabular}

${ }^{\mathrm{a}}$ Returns for Japan do not include data for 2000.

Numbers in parentheses are standard deviations.

***, **, and * December through May returns are significantly different from June-November at .01, .05, and .10 levels, respectively. 
To ensure the significant differences between December-May and June-November are not due simply to the January effect, we compute our statistics without January's return data. According to the significant ANOVA results ( $p$-value < .10) shown in Panel B of Table 4, the seasonal return pattern for each G7 country is an anomaly beyond the January effect.

We conducted ANOVA to test the semi-year effect for each country in each decade k: 1960s, 1970s, 1980s, 1990s (through 2001). Table 5 contains the mean six-month return results by decade. The hypotheses are:

$\mathbf{H}_{\mathbf{0 4}}: \quad \mathbf{r}_{\mathrm{ik} \text { Dec-May }}=\mathbf{r}_{\mathrm{ik} \text { Jun-Nov }}$

$\mathrm{H}_{\mathrm{a} 4}: \quad \mathbf{r}_{\mathrm{ik} \text { Dec-May }} \neq \mathbf{r}_{\mathrm{ik} \text { Jun-Nov }}$

The returns in December-May appear higher than in June-November for every country in every decade. However, we find the pattern of statistical significance over these six-month periods is as fickle as the January effect. The U.K. has significant patterns in each decade $(p$-value $<.10)$. In the 1960s the difference in returns is significant for only the U.K. In the 1970s the U.K., Japan, and Germany have significant patterns. In the 1980s it is the U.K., Japan, and France that have significant patterns, and in the 1990s through 2001 all G7 countries exhibit significant patterns except Japan. Contrary to the January effect results, the semi-year anomaly prevails in more countries in recent years.

We re-compute over the decades the semi-year returns without January returns. See Table 6 . The results do not dramatically change. The returns in December-May appear higher than in June-November for every country in every decade except in the case of Germany in the 1960s. Significant differences, however, are rare in the earlier decades. All the countries, including Japan, exhibit significant patterns in the 1990s through 2001.

\subsection{Discussion and Conclusions}

The anomaly called the January effect occurs when the January mean stock return is significantly higher than mean returns in the remaining months. Our study verified the higher January returns in all G7 countries in the years 1960 to 2001 . However, when the data is analyzed by decade, the January effect is most widespread in the 1970s. Haugen and Jorion (1996) found the U.S. January effect concentrated in the years 1974 to 1978. The January effect is relatively uncommon to the G7 countries in the other three decades studied. Greater integration of world markets are consistent with a less common January effect.

Our data and the data from other studies suggest there is a much broader seasonal pattern in stock return data. Over the 1960 to 2001 period, we find the mean monthly returns from December through May are significantly higher than mean returns in June through November. A further test confirms the significance of the semi-year pattern is not caused by the January effect alone. As with tests of the January effect, this seasonal effect is not consistent across all countries across all decades. But unlike the January effect, the semi-year effect is most common in the recent periods. The latter result certainly is inconsistent with more integrated and informationally-efficient world capital markets.

\subsection{Suggestions for Future Research}

A useful direction for future research would be toward explaining the semi-year pattern revealed in this study. Other databases or indexes may be useful. It is interesting to note that the seasonal pattern is consistent with the length of the days in the northern hemisphere. Returns are higher during the months when the days are lengthening. They are lower during the months when days are shortening. 
TABLE 5: ANOVA by Decade of Mean Monthly Returns of December-May versus June-November

\begin{tabular}{|c|c|c|c|c|c|c|c|c|}
\hline Country & Dec-May & Jun-Nov & F-value & $p$-value & Dec-May & Jun-Nov & F-value & $p$-value \\
\hline Panel A: 1960-1969 & & & & & \multicolumn{4}{|c|}{ Panel C: $1980-1989$} \\
\hline U.S. & $\begin{array}{l}0.65 \\
(2.91)\end{array}$ & $\begin{array}{r}0.16 \\
(3.04)\end{array}$ & 0.829 & .364 & $\begin{array}{l}1.24 \\
(3.15)\end{array}$ & $\begin{array}{c}0.87 \\
(4.27)\end{array}$ & 0.291 & .590 \\
\hline U.K. & $\begin{array}{l}0.95^{*} \\
(3.02)\end{array}$ & $\begin{array}{c}-0.17 \\
(3.59)\end{array}$ & 3.462 & .065 & $\begin{array}{l}2.39 * * \\
(3.51)\end{array}$ & $\begin{array}{r}0.55 \\
(4.92)\end{array}$ & 5.521 & .020 \\
\hline Canada & $\begin{array}{l}0.97 \\
(3.29)\end{array}$ & $\begin{array}{c}0.17 \\
(3.60)\end{array}$ & 1.591 & .210 & $\begin{array}{l}1.08 \\
(4.88)\end{array}$ & $\begin{array}{r}0.52 \\
(5.72)\end{array}$ & 0.331 & .566 \\
\hline Japan & $\begin{array}{l}1.48 \\
(3.85)\end{array}$ & $\begin{array}{l}-0.02 \\
(6.69)\end{array}$ & 2.273 & .134 & $\begin{array}{l}2.63 * * * \\
(3.24)\end{array}$ & $\begin{array}{c}0.57 \\
(3.16)\end{array}$ & 12.475 & .001 \\
\hline France & $\begin{array}{l}0.38 \\
(4.60)\end{array}$ & $\begin{array}{l}-0.13 \\
(4.49)\end{array}$ & 0.383 & .537 & $\begin{array}{l}2.62^{*} \\
(7.54)\end{array}$ & $\begin{array}{r}0.49 \\
(5.77)\end{array}$ & 3.032 & .084 \\
\hline Germany & $\begin{array}{l}0.62 \\
(4.62)\end{array}$ & $\begin{array}{r}0.47 \\
(6.14)\end{array}$ & 0.023 & .879 & $\begin{array}{l}1.21 \\
(3.91)\end{array}$ & $\begin{array}{r}0.79 \\
(4.76)\end{array}$ & 0.288 & .592 \\
\hline Italy & $\begin{array}{l}0.33 \\
(5.12)\end{array}$ & $\begin{array}{c}-0.08 \\
(5.02)\end{array}$ & 0.191 & .663 & $\begin{array}{l}3.46 \\
(6.83)\end{array}$ & $\begin{array}{c}1.02 \\
(9.20)\end{array}$ & 2.737 & .101 \\
\hline \multicolumn{5}{|l|}{ Panel B: 1970-1979 } & \multicolumn{4}{|c|}{ Panel D: 1990-2001 } \\
\hline U.S. & $\begin{array}{l}0.74 \\
(4.02)\end{array}$ & $\begin{array}{c}-0.32 \\
(3.44)\end{array}$ & 2.377 & .126 & $\begin{array}{l}1.31^{*} \\
(2.89)\end{array}$ & $\begin{array}{c}0.36 \\
(3.24)\end{array}$ & 3.458 & .065 \\
\hline U.K. & $\begin{array}{l}2.40 * * * \\
(8.12)\end{array}$ & $\begin{array}{l}-1.12 \\
(5.25)\end{array}$ & 7.936 & .006 & $\begin{array}{l}1.08 \\
(3.05)\end{array}$ & $\begin{array}{r}-0.10 \\
(3.51)\end{array}$ & 4.667 & .032 \\
\hline Canada & $\begin{array}{l}1.06 \\
(4.64)\end{array}$ & $\begin{array}{c}0.12 \\
(4.69)\end{array}$ & 1.225 & .271 & $\begin{array}{l}1.28^{*} \\
(4.07)\end{array}$ & $\begin{array}{c}-0.14 \\
(4.98)\end{array}$ & 3.488 & .064 \\
\hline Japan $^{\text {a }}$ & $\begin{array}{l}1.82 * * * \\
(4.22)\end{array}$ & $\begin{array}{l}-0.02 \\
(3.32)\end{array}$ & 7.050 & .009 & $\begin{array}{l}0.19 \\
(5.27)\end{array}$ & $\begin{array}{l}-1.18 \\
(4.95)\end{array}$ & 2.361 & .127 \\
\hline France & $\begin{array}{l}1.39 \\
(9.09)\end{array}$ & $\begin{array}{r}-0.36 \\
(5.30)\end{array}$ & 1.653 & .201 & $\begin{array}{l}2.08 * * * \\
(4.12)\end{array}$ & $\begin{array}{r}-0.60 \\
(4.86)\end{array}$ & 12.753 & .000 \\
\hline Germany & $\begin{array}{l}0.67 * * * \\
(3.70)\end{array}$ & $\begin{array}{c}-0.98 \\
(2.87)\end{array}$ & 7.435 & .007 & $\begin{array}{l}1.88^{* * * *} \\
(\mathbf{3 . 8 0})\end{array}$ & $\begin{array}{r}-0.76 \\
(\mathbf{5 . 0 1 )}\end{array}$ & 12.633 & .001 \\
\hline Italy & $\begin{array}{l}0.10 \\
(5.85)\end{array}$ & $\begin{array}{r}-0.30 \\
(8.84)\end{array}$ & 0.082 & .775 & $\begin{array}{l}2.64 * * * \\
(5.59)\end{array}$ & $\begin{array}{l}-1.25 \\
(5.84)\end{array}$ & 16.631 & .000 \\
\hline
\end{tabular}

Returns for Japan do not include data for 2000.

Numbers in parentheses are standard deviations.

***, ** and * December through May returns are significantly different from June through November returns at .01, .05 and .10 levels, respectively. 


\section{Volume 19, Number 3}

TABLE 6: ANOVA by Decade of Mean Monthly Returns of December-May versus June-November Without January Returns

\begin{tabular}{|c|c|c|c|c|c|c|c|c|}
\hline Country & Dec-May & Jun-Nov & F-value & $p$-value & Dec-May & Jun-Nov & F-value & $p$-value \\
\hline \multicolumn{4}{|c|}{ Panel A: 1960-1969 } & \multicolumn{5}{|c|}{ Panel C: $1980-1989$} \\
\hline U.S. & $\begin{array}{l}0.57 \\
(2.85)\end{array}$ & $\begin{array}{c}0.16 \\
(3.04)\end{array}$ & 0.536 & $\begin{array}{l}.466 \\
(3.13)\end{array}$ & $\begin{array}{l}1.08 \\
(4.27)\end{array}$ & 0.87 & 0.084 & .773 \\
\hline U.K. & $\begin{array}{l}0.82 \\
(3.16)\end{array}$ & $\begin{array}{l}-0.17 \\
(3.59)\end{array}$ & 2.324 & $\begin{array}{l}.130 \\
(3.49)\end{array}$ & $\begin{array}{l}2.12 * \\
(4.92)\end{array}$ & 0.55 & 3.571 & .061 \\
\hline Canada & $\begin{array}{l}0.71 \\
(3.10)\end{array}$ & $\begin{array}{c}0.17 \\
(3.60)\end{array}$ & 0.685 & $\begin{array}{l}.410 \\
(4.48)\end{array}$ & $\begin{array}{l}0.88 \\
(5.72)\end{array}$ & 0.52 & 0.133 & .716 \\
\hline Japan & $\begin{array}{l}0.83 \\
(3.72)\end{array}$ & $\begin{array}{l}-0.02 \\
(6.69)\end{array}$ & 0.643 & $\begin{array}{l}.424 \\
(3.35)\end{array}$ & $\begin{array}{l}2.52^{* * * *} \\
(3.16)\end{array}$ & 0.57 & 9.843 & .002 \\
\hline France & $\begin{array}{l}0.30 \\
(4.31)\end{array}$ & $\begin{array}{c}-0.13 \\
(4.49)\end{array}$ & 0.260 & $\begin{array}{l}.611 \\
(7.85)\end{array}$ & $\begin{array}{l}2.57 \\
(5.77)\end{array}$ & 0.49 & 2.563 & .112 \\
\hline Germany & $\begin{array}{l}0.41 \\
(4.57)\end{array}$ & $\begin{array}{r}0.47 \\
(6.14)\end{array}$ & 0.003 & $\begin{array}{l}.958 \\
(3.68)\end{array}$ & $\begin{array}{l}1.29 \\
(4.76)\end{array}$ & 0.79 & 0.368 & .545 \\
\hline Italy & $\begin{array}{l}0.24 \\
(4.99)\end{array}$ & $\begin{array}{c}-0.08 \\
(5.02)\end{array}$ & 0.108 & $\begin{array}{l}.744 \\
(6.66)\end{array}$ & $\begin{array}{l}2.91 \\
(9.20)\end{array}$ & 1.02 & 1.478 & .227 \\
\hline \multicolumn{4}{|c|}{ Panel B: 1970-1979 } & \multicolumn{5}{|c|}{ Panel D: 1990-2001 } \\
\hline U.S. & $\begin{array}{l}0.37 \\
(3.95)\end{array}$ & $\begin{array}{l}-0.32 \\
(3.44)\end{array}$ & 0.950 & $\begin{array}{l}.332 \\
(2.97)\end{array}$ & $\begin{array}{l}1.35^{*} \\
(3.24)\end{array}$ & 0.36 & 3.242 & .074 \\
\hline U.K. & $\begin{array}{l}1.98 * * \\
(8.36)\end{array}$ & $\begin{array}{l}-1.12 \\
(5.25)\end{array}$ & 5.602 & $\begin{array}{l}.020 \\
(3.16)\end{array}$ & $\begin{array}{l}0.97 * \\
(3.51)\end{array}$ & -0.10 & 3.368 & .069 \\
\hline Canada & $\begin{array}{l}0.61 \\
(4.10)\end{array}$ & $\begin{array}{r}0.12 \\
(4.69)\end{array}$ & 0.335 & $\begin{array}{l}.564 \\
(4.16)\end{array}$ & $\begin{array}{l}1.31^{*} \\
(4.98)\end{array}$ & -0.14 & 3.219 & .075 \\
\hline Japan $^{\text {a }}$ & $\begin{array}{l}1.27^{*} \\
(4.20)\end{array}$ & $\begin{array}{l}-0.02 \\
(3.32)\end{array}$ & 3.231 & $\begin{array}{l}.075 \\
(5.48)\end{array}$ & $\begin{array}{l}0.54^{*} \\
(4.95)\end{array}$ & -1.18 & 3.259 & .074 \\
\hline France & $\begin{array}{l}0.15 \\
(6.50)\end{array}$ & $\begin{array}{l}-0.36 \\
(5.30)\end{array}$ & 0.205 & $\begin{array}{l}.651 \\
(4.02)\end{array}$ & $\begin{array}{l}2.02 * * * \\
(4.86)\end{array}$ & -0.60 & 11.134 & .001 \\
\hline Germany & $\begin{array}{l}0.25 * * \\
(3.70)\end{array}$ & $\begin{array}{l}-0.98 \\
(2.87)\end{array}$ & 3.839 & $\begin{array}{l}.053 \\
(3.73)\end{array}$ & $\begin{array}{l}1.58^{* * * *} \\
(5.01)\end{array}$ & -0.76 & 8.943 & .003 \\
\hline Italy & $\begin{array}{l}0.12 \\
(5.97)\end{array}$ & $\begin{array}{l}-0.30 \\
(8.84)\end{array}$ & 0.081 & $\begin{array}{l}.776 \\
(5.43)\end{array}$ & $\begin{array}{l}2.03 * * * \\
(5.84)\end{array}$ & -1.25 & 10.997 & .001 \\
\hline
\end{tabular}

${ }^{a}$ Returns for Japan do not include data for 2000.

Numbers in parentheses are standard deviations.

***, ** and * December through May (excluding January) returns are significantly different from June through November returns at .01, .05 and .10 levels, respectively. 
Acknowledgments: The authors thank two anonymous reviewers for helpful comments and suggestions.

\section{References}

1. Agrawal, Anup and Kishore Tandon, "Anomalies or Illusions? Evidence from Stock

1. Markets in Eighteen Countries," Journal of International Money and Finance, 13, pp. 83-106, 1994.

2. Alford, Alan, "Assessing the Level of Capital Market Integration: A Review of the Literature," International Financial Market Integration, edited by S. Stansell, Basil Blackwell, Cambridge, Massachusetts, pp. 3-25, 1993.

3. Alford, Alan and Daryl M. Guffey, “A Re-examination of International Seasonalities," Review of Financial Economics, 5(1), pp. 1-17, 1996.

4. Bhabra, Harjeet S, Upinder S. Dhillon, and Gabriel G. Ramirez, "A November Effect? Revisiting the TaxLoss-Selling Hypothesis," Financial Management, 28(4), pp. 5-15, Winter 1999.

5. Blume, M.E. and R. F. Stambaugh, "Biases in Computed Returns: An Application to the Size Effect," Journal of Financial Economics, pp. 387-404, November 1983.

6. Chen, Carl R. and Anthony Chan, "From T-bills to stocks: Seasonal Anomalies Revisited," Journal of Business Finance and Accounting, 24(5), pp. 573-593, June 1997.

7. Chien, Chin-Chen, Cheng-few Lee, and Andrew Wang, "A Note on Market Seasonality: The Impact of Stock Price Volatility on the Application of Dummy Variable Regression Model," Quarterly Review of Economics and Finance, 42(1), pp. 155-162, Spring 2002.

8. DeBondt, W.F.M. and Richard Thaler, "Further Evidence on Investor Overreaction and Stock Market Seasonality," Journal of Finance, pp. 557-582, July 1987.

9. Durham, J. Benson, "Sensitivity Analyses of Anomalies in Developed Stock Markets," Journal of Banking and Finance, 25(8), pp. 1503-1541, 2001.

10. Economic Time Series Page, URL: http://www.economagic.com, December 1997.

11. Gultekin, Mustafa and N. Bulent Gultekin, "Stock Market Seasonality, International Evidence," Journal of Financial Economics, 12, pp. 469-481, 1983.

12. Haugen, Robert A. and Phillippe Jorion, "The January Effect: Still There after All These Years," Financial Analysts Journal, pp. 27-31, January-February 1996.

13. Jones, S.L. and W. Lee, "Evidence on the Behavior of Bid and Ask Prices at the Turn of the Year: Implications for the Survival of Stock Return Seasonality," Journal of Financial Research, pp. 383-400, Winter 1995.

14. Roll, Richard, "On Computing Mean Returns and the Small Firm Effect," Journal of Financial Economics, pp. 371-386, 1983.

15. Rozeff, M.S. and W.R. Kinney, Jr. "Capital Market Seasonality: The Case of Stock Returns," Journal of Financial Economics, pp. 379-402, October 1976,.

16. Survey of Current Business, "Historical Data for Selected Series," pp. C-38 to C-41, December 1994.

17. Survey of Current Business, "International Perspectives," p. C-5, November-December 1995.

18. Survey of Current Business, "International Perspectives," p. D-67, March 1997.

19. Survey of Current Business, "International Perspectives," p. D-63, January 1998.

20. Survey of Current Business, "International Perspectives," p. D-63, December 1998.

21. Survey of Current Business, "International Perspectives," p. D-63, June 1999.

22. Survey of Current Business, "International Perspectives," p. D-63, March 2000.

23. $\quad$ Survey of Current Business, "International Perspectives," p. D-63, May 2001.

24. Survey of Current Business, "International Perspectives," p. D-63, March 2002.

25. Survey of Current Business, "Sources for Business Cycle Indicators," pp. C-22 to C-25, March 1996. 